\title{
Millennium Development Goals - A Progress Report on Nigeria
}

\author{
Article by Eromon Aigbe Israel \\ PharmD, Texila American University, Nigeria \\ Email: aigbeeromon@gmail.com
}

\begin{abstract}
Millennium Development Goals (MDGs) are 8 international goals that were officially established following the millennium summit of the United Nations in 2000. Using Nigeria as a case study, there has been massive strides in attaining goals 1 to 6 while there has not been visible improvements in attaining goals 7 and 8. It is imperative for focus to shift to the rural areas where there is a higher demand for provision of basic healthcare and environmental infrastructure if these targets are to be met by 2015. Most importantly, the issues of poverty, universal basic education and health, and provision of safe drinking water will go a long way to improving the quality of life of over 160 million Nigerians.
\end{abstract}

\section{Introduction}

Millennium Development Goals (MDGs) are 8 international goals that were officially established following the millennium summit of the United Nations in 2000, as well as the adoption of the United Nation Millennium Declaration. The MDGs caught the world's imagination from the very day they were agreed by a record of 189 countries and 23 international organization at the UN General Assembly in September 2000, agreed to achieving those target. Each goal has agreed targets and indicators to track the progress made by each of the countries. Table 1 below shows the goals set at the millennium summit and the corresponding targets and indicators.

\section{Goal targets indicators}

Table 1: Millennium development goals(Available at http://siteresources.worldbank.org)

\begin{tabular}{|c|c|c|}
\hline $\begin{array}{l}\text { Goal 1: Eradicate } \\
\text { extreme poverty } \\
\text { and hunger }\end{array}$ & $\begin{array}{l}\text { - Target 1A: Halve, between } \\
1990 \text { and 2015, the } \\
\text { proportion of people living } \\
\text { on less than \$1.25 a day } \\
\text { Target 1B: Achieve Decent } \\
\text { Employment for Women, } \\
\text { Men, and Young People } \\
\text { - Target 1C: Halve, between } \\
1990 \text { and 2015, the } \\
\text { proportion of people who } \\
\text { suffer from hunger }\end{array}$ & $\begin{array}{ll}\text { - } & \text { Poverty gap ratio [incidence X } \\
& \text { depth of poverty] } \\
\text { - } & \text { Share of poorest quintile in } \\
\text { national consumption } \\
\text { - } & \text { GDP Growth per Employed } \\
\text { - } & \text { Eerson } \\
\text { - } & \text { Proportion of employed population } \\
\text { below } \$ 1.25 \text { per day (PPP values) }\end{array}$ \\
\hline $\begin{array}{l}\text { Goal 2: Achieve } \\
\text { universal primary } \\
\text { education }\end{array}$ & $\begin{array}{l}\text { Target 2A: By 2015, all } \\
\text { children can complete a } \\
\text { full course of primary } \\
\text { schooling, girls and boys }\end{array}$ & $\begin{array}{ll}\text { - } & \text { Enrolment in primary education } \\
\text { - } & \text { Completion of primary education }\end{array}$ \\
\hline $\begin{array}{l}\text { Goal 3: Promote } \\
\text { gender equality }\end{array}$ & $\begin{array}{ll} & \text { Target 3A: Eliminate } \\
& \text { gender disparity in primary }\end{array}$ & $\begin{array}{l}\text { Ratios of girls to boys in primary, } \\
\text { secondary and tertiary education }\end{array}$ \\
\hline
\end{tabular}


South American Journal of Public Health

Special Edition May 2016

\begin{tabular}{|c|c|c|}
\hline $\begin{array}{l}\text { and empower } \\
\text { women }\end{array}$ & $\begin{array}{l}\text { and secondary education } \\
\text { preferably by } 2005 \text {, and at } \\
\text { all levels by } 2015\end{array}$ & $\begin{array}{ll}\text { - } & \text { Share of women in wage } \\
\text { employment in the nonagricultural } \\
\text { sector } \\
\text { - } \\
\text { Proportion of seats held by women } \\
\text { in national parliament }\end{array}$ \\
\hline $\begin{array}{l}\text { Goal 4: Reduce } \\
\text { child mortality } \\
\text { rates }\end{array}$ & $\begin{array}{l}\text { Target 4A: Reduce by two- } \\
\text { thirds, between } 1990 \text { and } \\
\text { 2015, the under-five } \\
\text { mortality rate }\end{array}$ & $\begin{array}{ll} & \text { Under-five mortality rate } \\
\text { - } & \text { Infant (under 1) mortality rate } \\
\text { - } & \text { Proportion of 1-year-old children } \\
& \text { immunized against measles }\end{array}$ \\
\hline $\begin{array}{l}\text { Goal 5: Improve } \\
\text { maternal health }\end{array}$ & $\begin{array}{l}\text { - Target 5A: Reduce by three } \\
\text { quarters, between } 1990 \text { and } \\
\text { 2015, the maternal } \\
\text { mortality ratio } \\
\text { Target 5B: Achieve, by } \\
\text { 2015, universal access to } \\
\text { reproductive health }\end{array}$ & $\begin{array}{ll}\text { - } & \text { Maternal mortality ratio } \\
\text { - } & \text { Proportion of births attended by } \\
& \text { skilled health personnel } \\
\text { - } & \text { Contraceptive prevalence rate } \\
\text { - } & \text { Adolescent birth rate } \\
\text { - } & \text { Antenatal care coverage } \\
\text { - } & \text { Unmet need for family planning }\end{array}$ \\
\hline $\begin{array}{l}\text { Goal 6: Combat } \\
\text { HIV/AIDS, } \\
\text { malaria, and other } \\
\text { diseases }\end{array}$ & $\begin{array}{l}\text { Target 6A: Have halted by } \\
2015 \text { and begun to reverse } \\
\text { the spread of HIV/AIDS } \\
\text { Target 6B: Achieve, by } \\
\text { 2010, universal access to } \\
\text { treatment for HIV/AIDS } \\
\text { for all those who need it } \\
\text { Target 6C: Have halted by } \\
2015 \text { and begun to reverse } \\
\text { the incidence of malaria } \\
\text { and other major diseases }\end{array}$ & 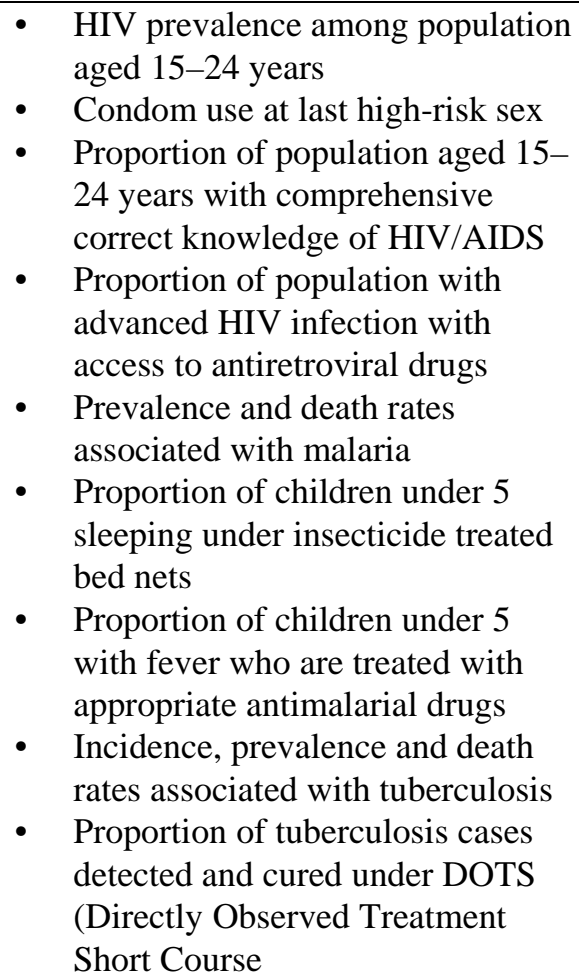 \\
\hline $\begin{array}{l}\text { Goal 7: Ensure } \\
\text { environmental } \\
\text { sustainability }\end{array}$ & $\begin{array}{l}\text { Target 7A: Integrate the } \\
\text { principles of sustainable } \\
\text { development into country } \\
\text { policies and programs; } \\
\text { reverse loss of } \\
\text { environmental resources } \\
\text { Target 7B: Reduce } \\
\text { biodiversity loss, } \\
\text { achieving, by 2010, a } \\
\text { significant reduction in the } \\
\text { rate of loss } \\
\text { Target 7C: Halve, by 2015, } \\
\text { the proportion of the }\end{array}$ & $\begin{array}{ll}\text { - } & \text { Proportion of land area covered by } \\
\text { forest } \\
\text { - }\end{array}$ \\
\hline
\end{tabular}




\begin{tabular}{|c|c|c|}
\hline & $\begin{array}{l}\text { population without } \\
\text { sustainable access to safe } \\
\text { drinking water and basic } \\
\text { sanitation } \\
\text { Target 7D: By 2020, to } \\
\text { have achieved a significant } \\
\text { improvement in the lives of } \\
\text { at least } 100 \text { million slum- } \\
\text { dwellers }\end{array}$ & $\begin{array}{ll} & \text { with extinction } \\
\text { - } & \text { Proportion of population with } \\
\text { sustainable access to an improved } \\
\text { water source, urban and rural } \\
\text { - } \quad \text { Proportion of urban population } \\
\text { with access to improved sanitation } \\
\text { - } \\
\text { Proportion of urban population } \\
\text { living in slums }\end{array}$ \\
\hline $\begin{array}{l}\text { Goal 8: Develop } \\
\text { a global } \\
\text { partnership for } \\
\text { development }\end{array}$ & $\begin{array}{l}\text { Target 8A: Develop further } \\
\text { an open, rule-based, } \\
\text { predictable, non- } \\
\text { discriminatory trading and } \\
\text { financial system } \\
\text { Target 8B: Address the } \\
\text { Special Needs of the Least } \\
\text { Developed Countries } \\
\text { (LDCs) } \\
\text { Target 8C: Address the } \\
\text { special needs of landlocked } \\
\text { developing countries and } \\
\text { small island developing } \\
\text { States } \\
\text { Target 8D: Deal } \\
\text { comprehensively with the } \\
\text { debt problems of } \\
\text { developing countries } \\
\text { through national and } \\
\text { international measures in } \\
\text { order to make debt } \\
\text { sustainable in the long term } \\
\text { Target 8E: In co-operation } \\
\text { with pharmaceutical } \\
\text { companies, provide access } \\
\text { to affordable, } \\
\text { essential drugs in } \\
\text { developing countries } \\
\text { Target 8F: In co-operation } \\
\text { with the private sector, } \\
\text { make available the benefits } \\
\text { of new technologies, } \\
\text { especially information and } \\
\text { communications }\end{array}$ & $\begin{array}{l}\text { - Includes a commitment to good } \\
\text { governance, development, and } \\
\text { poverty reduction - both nationally } \\
\text { and internationally } \\
\text { - Includes: tariff and quota free } \\
\text { access for LDC exports; enhanced } \\
\text { programme of debt relief for HIPC } \\
\text { and cancellation of official } \\
\text { bilateral debt; and more generous } \\
\text { ODA (Official Development } \\
\text { Assistance) for countries } \\
\text { committed to poverty reduction } \\
\text { Through the Programme of Action } \\
\text { for the Sustainable Development } \\
\text { of Small Island Developing States } \\
\text { and the outcome of the twenty- } \\
\text { second special session of the } \\
\text { General Assembly } \\
\text { Some of the indicators listed } \\
\text { below are monitored separately for } \\
\text { the least developed countries } \\
\text { (LDCs), Africa, landlocked } \\
\text { developing countries and small } \\
\text { island developing States. } \\
\text { Official development assistance } \\
\text { (ODA): } \\
\text { Net ODA, total and to LDCs, as } \\
\text { percentage of OECD/DAC donors' } \\
\text { GNI } \\
\text { Proportion of total sector allocable } \\
\text { ODA of OECD/DAC donors to } \\
\text { basic social services (basic } \\
\text { education, primary health care, } \\
\text { nutrition, safe water and } \\
\text { sanitation) } \\
\text { Proportion of bilateral ODA of } \\
\text { OECD/DAC donors that is untied } \\
\text { ODA received in landlocked } \\
\text { countries as proportion of their } \\
\text { GNIs } \\
\text { ODA received in small island } \\
\text { developing States as proportion of } \\
\text { Mair } \\
\text { - }\end{array}$ \\
\hline
\end{tabular}




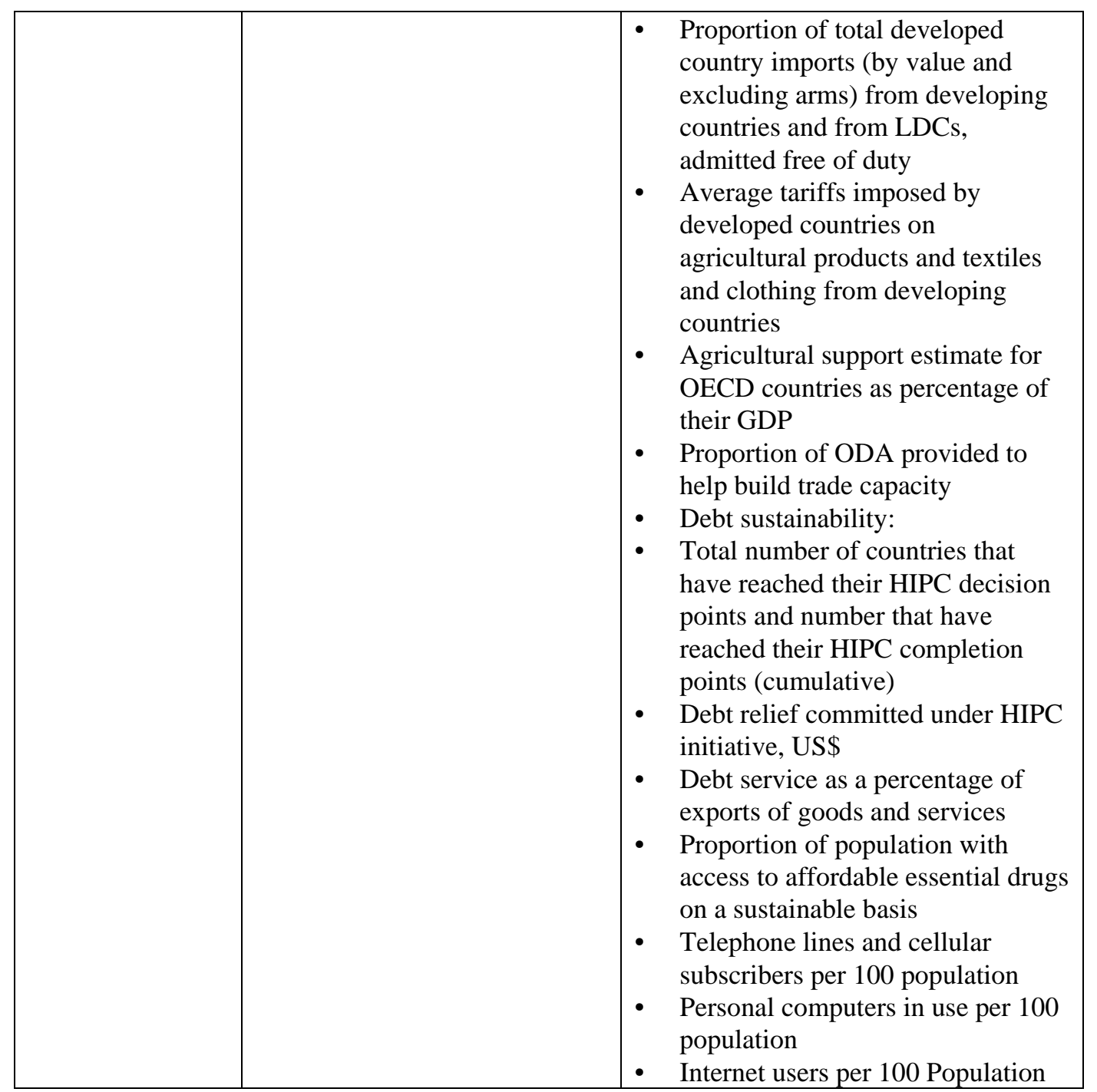

One thing of note is that progress has been uneven among countries and disparities vary across board for all the goals. Nigeria was an enthusiastic signatory to the MDGs and has claimed to pursue them vigorously since then, though with varying degrees of success. While MDGs are for all mankind, they are primarily about children, in part because children are the most vulnerable when essentials like food, water, and healthcare are scarce. Children are always the first victims, six of the eight goals relates directly to children. In order to meet the goals, the Office of the Senior Special Assistant to the President on the Millennium Development Goals (OSSAPMDGs) was created in 2005 to provide guidance, coordination and oversight of the debt-relief gains (DRGs) while working alongside partners and other actors. The Senior Special Assistant to the President is supported by a Director and Heads of Desks, who are in charge of supervision and policy formulation and implementation of various initiatives and programmes designed to achieve the MDGs. Since its creation, OSSAP-MDGs had concentrated its efforts on the provision of additional funding to critical sectors to improve Nigeria's chances of meeting the MDGs.

This review seeks to analyze the progress made by the policy stakeholders to ensure that the set targets are met before 2015 . 


\section{Objectives}

The aim of the report is to assess the progress made so far by Nigeria to ensure that the set millennium development goals are met by 2015. Data was sourced from the Nigerian intergovernmental agencies as well as the United Nations Development Program (UNDP) in Nigeria. It is important to note that the first report on Millennium development goals in Nigeria was published in 2004. Subsequently, two updated reports have been published in 2010 and 2014.

\section{Discussion}

The aim of the first goal is to reduce extreme poverty and hunger. Nigeria is still far from Target $1 \mathrm{~A}$ which aims to halve the proportion of people whose income is less than a dollar. Presently, Nigeria has $61.2 \%$ of people living on incomes less than $\$ 1$ a day where the MDG target is $21.4 \%$. Poverty eradication programmes have not been able to reduce unemployment rates and it remains a socioeconomic burden. The Economic Transformation Agenda hopes to focus more attention on agriculture, electricity generation and infrastructure development which in turn, should stimulate the economy to provide jobs to most of the $23 \%$ of unemployed Nigerians. However, Nigeria has been able to maintain its stance in meeting this target of reducing the proportion of people who suffer from hunger and prevalence of underweight children through the Federal Ministry of Agriculture and Rural Development. Some of these measures include subsided sales of fertilizers, seeds and agricultural equipment to farmers, strengthening of distribution chain of staple foods and crops, as well as training of farmers on the importance of mechanized farming. Efforts have also been geared towards reducing imports of agricultural products and encouraging local produce for nationwide consumption via poverty eradication programmes. The efforts of this programme has been recognized by the Food and Agriculture Organisation of the United Nations which listed Nigeria as one of the countries set to meet the target of reducing hunger by half among its population.

The second goal aims to achieve universal primary education. The policies put in place by the federal government have increased access to basic primary education through enrolment of children. According to the Nigerian Bureau of Statistics, enrolment of children into primary schools has increased from 68\% in 1999 to $89 \%$ in 2012 while the literacy rate for $15-24$ year olds has risen from $60 \%$ in 2000 to $80 \%$ in 2008 . The government through the OSSAP-MDGs has also reviewed the Federal Teachers' scheme and continuous training for teachers to improve the quality of teaching. It is hoped that these efforts will ensure that the set target of $100 \%$ is achieved. A major issue to be addressed is the retention of female children in school until completion in some parts of the country.

The third goal seeks to promote gender equality and empower women to be role models and decision makers in positions of power. There has been a steady increase in the number of girls attaining primary, secondary and tertiary education which has seen a ratio of 9 girls for every 10 boys in school. The proportion of seats held by women in parliament has also risen from 1\% in 1990 to $7 \%$ in 2012. This is a remarkable feat that has been recorded through collaboration between the federal and state governments and implementation of the National Gender Policy. However, this figures is still far from the target of $35 \%$ set to be implemented by the National Gender Policy.

The fourth goal aims to reduce the infant mortality rate by as much as $66 \%$ by the year 2015. Between 1990 and 2012, there has been a reduction in number of infant deaths from 91 deaths per 1000 live births to 61 deaths per 1000 live births. Under-five mortality has also dropped from 191 deaths per 1000 live births to 94 deaths per 1000 live births while there has been a marginal increase of one-year old children immunized against measles from $46 \%$ to $61 \%$. The Federal Government has recognised that these activities fall short of the target set and has adopted the integrated maternal, newborn and child health strategy in order to meet the 2015 deadline. 
South American Journal of Public Health

Special Edition May 2016

The fifth goal targets improvement and access to maternal health in the population. Nigeria has fared considerably well in the reduction of maternal mortality from 1000 deaths per 100,000 live births in 1990 to 350 deaths in 100,000 live births in 2012. The proportion of births handled by skilled health personnel has also risen marginally from 45\% in 1990 to 53\% in 2012. This activity is being catalyzed by the implementation of the Midwives Service Scheme which involves the training of community health workers on basic skills for the provision of maternal and child health services. This scheme is targeted at the rural areas where access to quality healthcare is not available and this has helped to reduce the number of births that take place at home. It has also increased antenatal coverage from $61 \%$ in 2004 to $67.7 \%$ in 2012 (at least one visit by any provider) and 47\% in 2004 to $57.7 \%$ in 2012 (at least four visits by any provider). Efforts are still underway to achieve universal access to reproductive health by 2015 although the indicators show improvement from the baselines. However, challenges such as cultural and religious barriers limit access of these services at the grassroots level.

The sixth millennium development goal focuses on the fight against HIV/AIDS, malaria and other diseases. The government with funding assistance from international health agencies have been able to halt the spread of HIV. The indicator shows that HIV prevalence among pregnant women $15-24$ years old has reduced from $5.4 \%$ in 2000 to $4.1 \%$ in 2010 . The measures put in place include provision of contraceptives and family planning services, testing platforms for diagnosis, availability of antiretroviral drugs and counseling services. However, access to comprehensive information on HIV/AIDS and reported use of condoms by people aged 15-24 years is still low and might not be met by 2015. Malaria is one of the leading causes of mortality in Nigeria with $90 \%$ of the population at risk. One of the preventive strategies has been the use of long lasting insecticide treated nets (LLINs). The proportion of children under five years of age sleeping under LLINs has risen from $5.5 \%$ in 2008 to $18.0 \%$ in 2011 . To date, a total of $46,903,594$

Long-lasting insecticide-treated nets (LLINs) have been distributed to populations at risk of malaria. In addition, the government is intensifying efforts in diagnosis and malaria prevention in pregnancy through affordable and available artemisinin-based therapy. There has also been a steady progress in the reduction of prevalence of tuberculosis deaths even though the country is categorized as a high burden for the disease. The latest figures show a drop in mortality rates from 15.74 per 100,000 in 2000 to 5.0 per 100,000 in 2012.

The seventh goal aims to ensure environmental sustainability and sadly enough, not much success has been achieved. Safe drinking water and sanitation remain unresolved probably as a result of lack of implementation of policies and funding. The government has also done little to improve the living conditions of slum dwellers because of population expansion at the urban level and increased unemployment rate. Environmental challenges such as flooding and bush burning have also frustrated efforts at halting the spread of deforestation which has affected wildlife and the environmental ecosystem.

The eight goal seeks to develop a global partnership for development. Even though a large chunk of Nigeria's external debt was written off by the Paris Club in 2005, the money meant to service these debts have not been adequately channeled into the social sector to meet the millennium target goals. As a developing country, there is need to still seek for donor aid and assistance to tackle the socioeconomic problems. However, access to internet and telephony services have improved due to privatization of the telecommunications sector. According to the National Communications Commission, 30 in every 100 people have access to the internet while 60 in every 100 people have access to telephone services.

\section{Conclusion}

There has been massive strides in attaining goals 1 to 6 while there has not been visible improvements in attaining goals 7 and 8. It is imperative for focus to shift to the rural areas where there is a higher demand for provision of basic healthcare and environmental infrastructure if these targets are to be met by 2015. Most importantly, the issues of poverty, 
universal basic education and health, and provision of safe drinking water will go a long way to improving the quality of life of over 160 million Nigerians. The data collection methods should be consistent and reliable for easy interpretation and accurate decision making.

It is expected that the various policies, if properly implemented and funded will help to prepare the country for socioeconomic development after 2015.

\section{References}

[1.] Abani, C., Igbuzor, O. and Moru, J. (2005),Attaining the Millennium Development Goals in Nigeria: Indicative Progress and a Call for Action. In Moru, J. (Ed), Another Nigeria is Possible: Proceedings of the First Nigeria Social Forum. Abuja, Nigeria Social Forum.

[2.] Federal Ministry of Agriculture and Rural Development (2012). Agricultural transformation agenda: execution and delivery for 2012 by Honorable Minister of Agriculture and Rural Development. Abuja: Federal Ministry of Agriculture and Rural Development.

[3.] Federal Republic of Nigeria (FRN) (2010),The MDGDRG funded Midwives Service Scheme: concept, process and progress. Abuja: National Primary Health Care Development Agency.

[4.] List of goals, targets, and indicators. Available at http://siteresources.worldbank.org

[5.] National Agency for the Control of HIV/AIDS (2011).Factsheet 2011: update on the HIV/AIDS epidemic and response in Nigeria. Abuja: National Agency for the Control of HIV/AIDS.

[6.] National Bureau of Statistics (NBS) (2009). Profile of Women and Men in Nigeria. Available at: www.nigerianstat.gov.ng.

[7.] National Gender Policy (2008). Retrieved from

http://nascp.gov.ng/demo/wpcontent/uploads/2014/02/National-Gender-Policy-Strategic-Framework2008-MWASD.pdf

[8.] National Population Commission (NPC), National Malaria Control Programme (NMCP) and ICF International (2012)Nigeria Malaria Indicator Survey (2010). Abuja: NPC, NMCP and IF International

[9.] Nigeria MDG Report (2010). Available at

http://www.mdgs.gov.ng/index.php/downloads/category/1-mdgs-general\#

[10.] Nigeria meets MDG 1 (n.d). Available at http://www.fao.org/countryprofiles/newsarticle/en/c/202569/

[11.] Obaji, C.N. (2005).Nigeria's experience with girls' education and linkages with action with adult female literacy to impact on poverty alleviation. Paper presented at the United Nations girls' education initiative, technical consultation, Beijing, China, 26-27 November. Available at:

http://www.ungei.org/beijing/nigeria_opening.html.

[12.] OSSAP-MDGs (2010).Nigeria Millennium Development Goals (MDGs) countdown strategy2010 to 2015: achieving the MDGs. Abuja: OSSAPMDGs.

[13.] UNDP Nigeria MDG Report (2013). Retrieved from

http://www.ng.undp.org/content/dam/nigeria/docs/MDGs/UNDP_NG_MDGsReport2013.pdf 